\title{
PEDAGOGICAL MODELLING OF DEVELOPMENT OF INFORMATION AND COMMUNICATION COMPETENCE OF PROFESSORS OF DISTANCE LEARNING MILITARY EDUCATION SYSTEM
}

\author{
Vasyl Yahupov, Vladyslav Kyva \\ ${ }^{1}$ Department of Social Sciences, National Defense University of Ukraine named after Ivan \\ Cherniakhovskyi, Kyiv, Ukraine \\ phone/ mobile: +380957539936, e-mail: yagupow1957@gmail.com \\ ${ }^{2}$ National Defense University of Ukraine named after Ivan Cherniakhovskyi, Kyiv, Ukraine \\ phone/ mobile: +380730741171, e-mail: kyvavlad30101991@gmail.com
}

\begin{abstract}
The present article describes the results of analysis of academic views on such terms as "a pedagogical model", "the modelling" and the possibilities to implement the pedagogical modelling in respect of a professor of the military education system. The pedagogical model of development of his/her information and communication competence in matters of distance learning was suggested and its main constituent elements as conceptual, insightful, methodic, effective, and, according to the requirements of the leading methodological approaches, informative, competence-based, subjectactivity, and contextual aspects were substantiated. The content of the key constituent elements of the present model was also described.
\end{abstract}

Keywords: model; pedagogical modelling; development; information and communication competence; constituent elements; professor.

\section{RESEARCH PROBLEM}

Currently, all realms of public production, including the system of national professional education, are essentially influenced by factors of an information society, namely the information and communication technologies establishing favorable conditions in order to provide the citizens with a wide range of educational services. One may say they are substantially improving the modern educational system at all levels, including the military education system providing training of personnel of military officers for the Armed Forces of Ukraine.

The network educational data centers and modern information and communication technologies may essentially contribute to improvement of military and professional training of the specialists as well as the professors. Special attention shall be drawn in particular to certain points of this aspect: firstly, it is ability of the professors to use these centers and technologies in their entirety in respect of educational, military and professional needs of cadets (students). Thus, it is necessary to stress that their information and communication training shall meet the requirements of the information society, of the one part, and of military domain extensively using the advanced information technologies, of the other part. Secondly, it is desirable the development and improvement of information and communication competence of cadets (students), military officers at higher educational establishments be active and ongoing since the information technologies are rapidly and regularly renovated and enhanced. Therefore, the professors are in need of constantly improving their professional and pedagogical competence and keeping themselves in line with the modern changes of the information society and of the Armed Forces of Ukraine [5].

Thus, upon the analysis and consolidation of academic papers on research of information and communication competence of various specialists, clarification of its structure and content, we fully realized the importance of elaboration of model of development of information and communication competence of the professors of the military education

IRTIIE Vol. 7, No. 3, 2019 ISSN 1314-8788 (print), ISSN 1314-8796 (online), doi: 10.15547/artte.2019.03.007 
system of distance learning. And therefore, it will give us a great opportunity to analyze, make a model and assess the main stages of pedagogical process related to its development of the professors of the military educational system.

\section{ANALYSIS OF RECENT RESEARCH AND ACADEMIC PAPERS}

The analysis of the academic papers and theses demonstrates that the elaboration of pedagogical models was examined thoroughly by such scholars as Anisimov M., Bilyk N., Walat V., Yezhova O., Zuwallack R., Campbell T., Kiriazis N., Kravchenko O., Krylova V., Lazariev M., Lodatko Ye., Meshchaninov O., Morozova Yu., Maughn M., Oh S.J., Semenova A., Oh P.S., Yakubovski M., and others. Some scholars as Hrabovskyi P., Dehtiarova H., Kocharian A., Fedoruk H., Servetnyk R., Tymofieieva I., Yahupov V. and others, pay much attention and put an emphasis on necessity to use modelling while investigating the pedagogical phenomena and processes.

Therefore, such scholars as Zuwallack R., Campbell T., Kiriazis N., Maughn M., Oh P.S. dedicated their works to conceptual issues on pedagogical modelling and defined it as the main feature of the pedagogical process consequently affecting the understanding of academic and pedagogical practicum and improvement/development of the object under research in whole [2].

For the purposes of finding clearer understanding of the pedagogical modelling, the following scholars - Oh S.J. and Oh P.S. - worked up five types of pedagogical modelling:

- Research modelling (research of characteristics of already existing model through interaction with it, namely by change of parameters and observation over effects);

- Expressional modelling (discussion and suggestion of own ideas in order to describe or explain the academic phenomena, namely by elaboration of new models or usage of existing ones);

- Experimental modelling (request modelling where the hypotheses and projections on models are elaborated and verified by experiments with the phenomena);

- Evaluation modelling (the alternative models related to the same phenomenon or problem are compared, their advantages and restrictions are assessed, and the most suitable option $(-s)$ in order to explain the phenomenon or solve the problem are selected);

- Repeated modelling (participation of scholars in the current processes of model elaboration and verification with its subsequent improvement, evaluation and implementation taking a lot time) [7].

The scholars find opinion of Walat $\mathrm{V}$. quite unusual; he reasonably insists on necessity of consistent purposeful implementation of modern information and communication technologies in their different forms into education system, for instance by multimedia means [11], in order to ensure quality of such education at all levels [12], including textbook modelling [10].

Thus, foreign and domestic scholars note the topicality of the present research direction and its heuristic aspect. For instance, while conducting pedagogical modelling they use such standard approaches and constituent parts being important for understanding of the key aspects of modelling related to the development of information and communication competence. However, these approaches and constituent parts have little in common and one shall take into consideration the various purposefulness of the pedagogical modelling and those conditions in which the respective models are to be implemented.

We also should emphasize on the absence of academic papers related to the pedagogical modelling in respect of development of information and communication competence of the professors of distance learning military education system. Pursuant thereto, it is important to elaborate the professionally-oriented model of its development according to the leading ideas of informative, competence-based, subject-activity, and contextual methodological approaches.

IRTIIE Vol. 7, No. 3, 2019 ISSN 1314-8788 (print), ISSN 1314-8796 (online), doi: 10.15547/artte.2019.03.007 


\section{ARTTIE $Y$}

Ipplied Researirches in Technics, Technologies and Rduration

Journal of the Faculty of Technics and Technologies, Trakia University https://sites.google.com/a/trakia-uni.bg/artte/

The purpose of the present article is to conduct the pedagogical modelling of development of information and communication competence of the professors of distance learning military education system.

\section{RESEARCH FINDINGS}

Currently, the pedagogical modelling method is one of the paramount methods of scientific cognition of the pedagogical phenomena and systems being sophisticated, multielement and polystructural in their essence. The modelling is the foundation of every research method, whether it is theoretical which uses the various abstract models or experimental when these models are verified.

In order to substantiate the models of development of information and communication competence of the professors of distance learning military education system one should take into account the approaches to interpretation of such crucial for our research terms as the modelling and a model. The modelling is usually interpreted by scholars as elaboration and examination of models of real subjects and phenomena, and objects that are created for the purposes of determination and improvement of their characteristics, rationalization of ways of their development and management [1, p. 683]; the method of phenomena and processes research based upon the substitution of the real object of research (an original object) with another one being similar to the former (a model object) [8, p. 12]; means of pedagogical research enabling to simulate the real and structural systems by analogues reconstituting the peculiarities of the objects and systems of the original objects in their organization and operation [9, p. 165].

Yahupov V. states that "the pedagogical modelling enables to elaborate the model of a specialist based upon his/her competence, to verify the model of professional competence as well as to work up the model of its development while obtaining professional education." [14, p. 146].

The present research interprets the pedagogical modelling as the research method related to the development of information and communication competence of the professors of military education system the result of which is the elaboration of respective pedagogical model. In the meantime, it is worth stressing that while working up the certain model the scholars have to pay no regard to some peripheral elements.

According to Honcharenko S., no model, even the most sophisticated, may provide comprehensive view of the research object and precisely predict its development, or describe its guidepath in its own space. Thus, the scholars are to operate on the fringes of comprehensiveness and validity while elaborating the models [3, p. 120]. We fall in with those views and affirm that the pedagogical modelling indeed has the peculiarities related to some sort of uncertainness and vagueness of the pedagogical terms, lack of standard procedures for testing of the results of change of the various pedagogical phenomena.

Thus, Lodatko Ye. reasonably underlines the pedagogical modelling has the following special features:

- Uncertainness, vagueness of the pedagogical terms;

- Sophistication, constant modification and localization of the pedagogical phenomena, objects and processes;

- Availability of criteria and means preventing the determination of the level of the desired goals achievement, measurement of results of the process implementation, definition of the qualitative assessment of the pedagogical phenomena, personal victories of the subjects of the pedagogical process, etc.;

- Social and cultural character of the research object with variety of practical application generating the complexity of its formalization [6].

Consequently, the term "model" is interpreted as the conventional scheme of some process

IRTIIE Vol. 7, No. 3, 2019 ISSN 1314-8788 (print), ISSN 1314-8796 (online), doi: 10.15547/artte.2019.03.007 


\section{ARTTIE $Y$}

Ipplied Reseiar

Journal of the Faculty of Technics and Technologies, Trakia University https://sites.google.com/a/trakia-uni.bg/artte/

or object used in research by its presenter according to the Big Dictionary of Ukrainian language [1, p. 683].

Pursuant to the Encyclopedia of Education, a model is the ideal or substantially implemented system displaying the research object and enabling to change that object in such a way that getting acquainted with it provides the new data on the object in question [4, p. 516].

According to Yahupov V., the model is the sign system by which it is possible to reconstitute the teaching process as the research object, show its structure and operation in their entirety, and preserve that cohesiveness at all research levels [13, p. 31].

I. Ziaziun states that a model is artificially elaborated pattern presented as a scheme, material constructions, signs or formulae which is similar to the object under research (or some phenomenon) which displays and reconstitutes the structure, peculiarities, interconnections, and relations between the constituent elements of this object in a simplified manner [15, p. 209].

Thus, the pedagogical model shall be considered as the multitude of interconnected constituent parts creating the coherent whole and demonstrating the common goal of the pedagogical process related to implementation of certain pedagogical conception and establishing pedagogical emergence. Hence, the peculiarity of the pedagogical modelling is that as the result the conceptual model of the pedagogical process (phenomenon, object) is elaborated and may be used for the purposes of projecting its formation, development, and improvement.

Consequently, the modelling of development of information and communication competence of a professor of distance learning military education system provides, as a sophisticated pedagogical process, the usage of certain methodological approaches among which we shall single out the informative, competence-based, subject-activity, and contextual approaches. They are closely intertwined and interdependent to some extent.

Thereafter, the informative approach provides the information saturation of the content of information and communication competence of a professor where one shall single out both conceptual and insightful aspects of its development. Its essential scope shall be used both in theoretical and practical learning materials. The development of the professors of military education system while having postgraduate study (self-education) stipulates the elaboration of the content of study in the domain of information and communication technologies being a cornerstone for the development of their information and communication competence. In practice, it almost means the program for its development.

Competence-based approach focuses on the results of education, i.e. training and qualification, aptitude and readiness of a specialist to act in a professional manner while having various challenging situations relating to the profession itself and including pedagogical ones.

Subject-activity approach provides, as a subject-related constituent element, the person who teaches, namely a professor of military education system, is placed in the core of education, his/her attitude, values and incentive for pedagogical activity, unique mental make-up as a subject of the social, professional and qualified being and reality.

The contextual approach serves as a guide for the providers of military education in order to work up the learning material pertaining to the interests of professors' professional activity, namely their training activity assumes contextual form. That encourages their cognitive concernment and performance since this process takes place in the framework of their pedagogical activity within the limits of those academic subjects that they teach. One may hold the contextual approach makes their professional activity practically directed and operates as a powerful motivating factor in the advanced training system being based upon the following: subjective activity of the professors in the academic practice provided respective psychological and pedagogical maintenance and support; the modelling of the further conditions of pedagogical activity; the assurance of interconnections of the subjects of

IRTIIE Vol. 7, No. 3, 2019 ISSN 1314-8788 (print), ISSN 1314-8796 (online), doi: 10.15547/artte.2019.03.007 


\section{ARTTIE $Y$}

Ipplied Resseirlohes in Technics, Technologies and Eductition

Journal of the Faculty of Technics and Technologies, Trakia University https://sites.google.com/a/trakia-uni.bg/artte/

educational process, i.e. between the professors and those who are studying; the incorporation of the modern technologies for pedagogical tuition and instruction; focus on practical aspects of the professor advanced training.

Thus, the pedagogical modelling of the present research has several stages:

1. Engagement into the problem of elaboration of the model of development of information and communication competence of the professors of distance learning military education system, determination of its place, role and functions in the system of their professional and advanced training.

2. Consistent vision of information and communication competence of the professors of military education system, in particular: identification of its structure, content and definition of insightful and methodic sequence; development and substantiation of the criteria and indicators of its testing.

3. Identification of the units of the pedagogical model of development of information and communication competence of the professors of military education system such as conceptual, insightful, methodic, effective units and setting up different connections between them, i.e. logical, insightful and informative, operative, technological and effective ones.

4. The model elaboration:

- the data on information and communication competence of the professors (historical, methodological, methodic, observational, experimental) are revealed by means of theoretical and observational research related to its object; the research targets are defined including the certain object for modelling, i.e. the development of information and communication competence of the professors of military education system;

- specification of the main pedagogical characteristics of development of information and communication competence of the professors that is detailed in its content, techniques and technologies, and in the key stages;

- substantiation of the technique for conducting the summative and formative stages of an experiment and working up of the evaluation criteria of their results;

- determination of cause-and-effect relationships of the pedagogical modelling, i.e. the effect of model incorporation into the pedagogical process related to the development of information and communication competence of the professors of distance learning military education system.

Pursuant to the special character of information and communication competence of the professors of military education system, the pedagogical model (fig. 1) of its development was elaborated and comprises the tasks of development of its constituent elements according to the goal. We shall briefly examine the purposefulness and content of its structural constituent elements in distance learning.

The conceptual unit enables to define the goal and the subordinated main tasks in respect of development of information and communication competence of the professors of military education system in conformity with the leading requirements of the modern methodological approaches as follows:

- development of value-based and motivational constituent element (values of academic and pedagogical activity with usage of information and communication technologies; motivation related to development of information and communication competence);

- development of intellectual constituent element (awareness of theory of information and communication technologies; awareness of theoretical basics of analysis and decisionmaking in the military domain; awareness of the technologies of process (phenomena) modelling while teaching the basic military and professional military disciplines; awareness of theoretical regulations of cybersecurity while using information and communication technologies while teaching the basic military and professional military disciplines; awareness of modern hardware and software; awareness of technologies for software development according to certain tutorial technique);

IRTIIE Vol. 7, No. 3, 2019 ISSN 1314-8788 (print), ISSN 1314-8796 (online), doi: 10.15547/artte.2019.03.007 


\section{ARTTIE $Y$}

Ipplied Resseirrches in Technicis, Technologies and Eductition

Journal of the Faculty of Technics and Technologies, Trakia University https://sites.google.com/a/trakia-uni.bg/artte/

- development of praxeological constituent element (ability to use information and communication technologies; ability to work up and use the modern hardware and software and their testing on cyber vulnerabilities);

- development of informative and technological constituent element (ability to use information and communication technologies in academic and pedagogical activity; ability to synthesize different software for advancement of tutorial efficiency of the basic military and professional military disciplines; ability to develop information software for the purposes of usage while teaching the basic military and professional military disciplines);

- the development of subjective constituent part (academic and pedagogical subjects in the information society; ability to self-assessment as a subject of information and analytical activity in framework of performance of functions of a professor of certain basic military and professional military disciplines).

The contextual unit displays the content of information and communication competence of the professors of military education system and comprises all necessary requirements for its development taking into consideration the modern achievements in psychological and pedagogical, and methodic spheres, information domain; it contributes to sequence, succession and continuity of its development.

The methodic unit provides gradual development of information and communication competence of the professors of military education system which may be implemented by arranged sequence of stages of its development. The present unit is represented by multitude of various forms, methods and means of organization of tutoring and learning being necessary for achievement of the desirable level of sophistication of information and communication competence of the professors. They enable to engage all the participants of pedagogical learning to joint activity given personal, academic and pedagogical interests, needs, opportunities and substantiate the sequence of development of each of the constituent elements of information and communication competence.

The effective unit includes the result of development of information and communication competence and of testing the levels of sophistication of its constituent elements of the professors of military education system with usage of the specified criteria and indicators (value-based and motivational, cognitive, technological, operational, reflexive). The main function of this unit is the identification of relevant dynamics and levels of their sophistication (low, medium, sufficient, high) of information and communication competence (in accordance with the constituent elements: value-based and motivational, intellectual, praxeological, informative and technological, subjective) by means of the elaborated technique of their testing. Pursuant to the determined levels of sophistication of professional competence the information for making changes in the process of its development emerges. Making changes is carried out through amendment of tasks, training content, organizational forms and methods of development of information and communication competence of the professors of military education system at the conversion courses and courses aimed at advanced training. In order to provide the efficiency of all the units of the model the pedagogical conditions of development of information and communication competence of the professors of distance learning military education system were determined. Among them we may single out: incorporation of distance learning technologies into the process of professional training of the professors of military education system with usage of modern information and communication technologies; motivation related to self-improvement of information and communication competence while having advanced training; the pedagogical modelling of development of information and communication competence of the professors of military education system in the sphere of advanced training.

The pedagogical conditions of development of information and communication competence shall have the meaning of an array of objective measures (content, organizational forms and methods) aimed at the fulfillment of the process of its development.

\section{IRTIII Vol. 7, No. 3, 2019 ISSN 1314-8788 (print), ISSN 1314-8796 (online), doi: 10.15547/artte.2019.03.007}




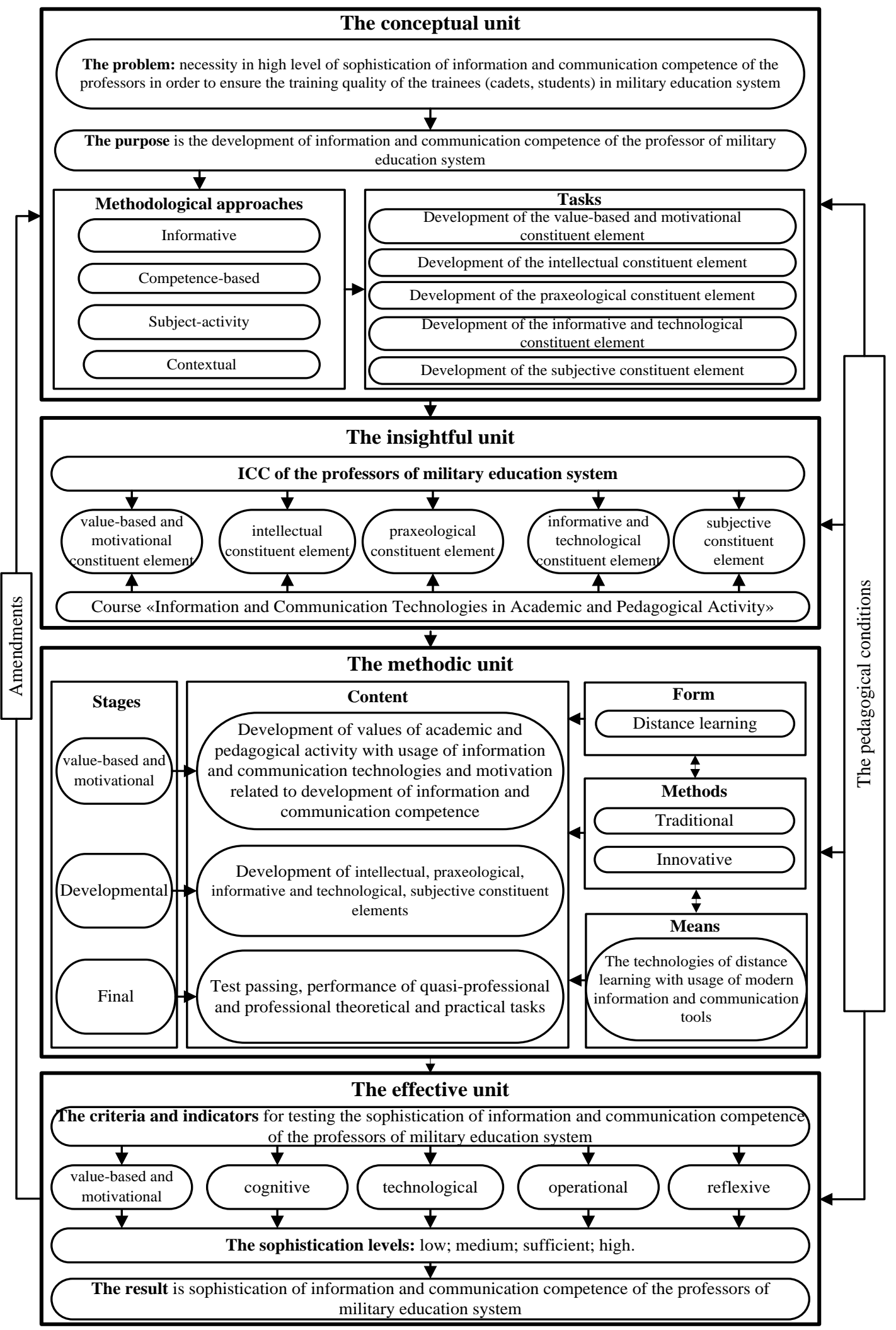

Figure 1. The model of development of information and communication competence of the professors of military education system.

IRTIIE Vol. 7, No. 3, 2019 ISSN 1314-8788 (print), ISSN 1314-8796 (online), doi: 10.15547/artte.2019.03.007 


\section{IRITIE Ipplied Resederches in Technicss, Technologies ind Bduriation Journal of the Faculty of Technics and Technologies, Trakia University https://sites.google.com/a/trakia-uni.bg/artte/}

\section{CONCLUSIONS AND DIRECTIONS FOR FURTHER RESEARCH}

1. Therefore, the pedagogical modelling is topical academic and pedagogical challenge for which the domestic and foreign scholars try to find some solutions. The analysis of academic papers made possible to ascertain the content of the key terms of pedagogical research, i.e. the modelling and a model.

2. It was found that modelling of development of information and communication competence of a professor of distance learning military education system provides, as a sophisticated pedagogical process, the usage of certain methodological approaches among which we should single out informative, competence-based, subject-activity, and contextual ones.

3. The pedagogical model of development of information and communication competence of the professors of distance learning military education system was elaborated and substantiated; the pedagogical conditions of its development were defined.

4. It was ascertained the pedagogical model of development of information and communication competence of the professors of distance learning military education system is the presentation of the purpose, tasks, academic approaches, principles, conditions and constituent elements, process organization, criteria and indicators of testing of the levels of its sophistication and clarification of connections between them.

The advanced directions for further research: verification of the elaborated model of development of information and communication competence of the professors of military education system at the distance learning conversion courses and courses aimed at advanced training.

\section{REFERENCES}

[1] Busel, V. T. (2005). The Big Dictionary of Modern Ukrainian Language (with additions and amendments). Kyiv, Ukraine.

[2] Campbell, T., Oh, P. S., Maughn, M., Kiriazis, N., \& Zuwallack, R. (2015). A Review of Modeling Pedagogies: Pedagogical Functions, Discursive Acts, and Technology in Modeling Instruction. Eurasia Journal of Mathematics, Science \& Technolog, Education,1 (11), 159-176.

[3] Honcharenko, S. U. (2008). Pedagogical Research: Methodological Pieces of Advice to Young Scholars. Vinnytsia, Ukraine.

[4] Kremen, V. H. (2008). The Encyclopedia of Education. Kyiv, Ukraine.

[5] Kyva, V. Y. (2018). Development of Information and Communication Competence of the Professors of Military Education System as a Methodological Problem, Adaptive Control. Theory and Practice. Series "Pedagogics",5 (9), 1-20. Retrieved July 30, 2019, from https://amtp.org.ua/index.php/journal/article/view/20/17.

[6] Lodatko, Y. O. (2010). The Modelling of Pedagogical Systems and Processes. Sloviansk, Ukraine.

[7] Oh, P. S., \& Oh, S. J. (2011). What teachers of science need to know about models: An overview. International Journal of Science Education, 33 (8), 1109-1130.

[8] Semychenko, V. A. (2000). The Modelling of Pedagogical Activity Structure. Yalta, Ukraine.

[9] Sushentseva, L. L. (2011). The Formation of Professional Mobility of Future Specialists in Vocational Educational Establishments. Kryvyi Rih, Ukraine.

[10] Walat, W. (2004). Modelowanie podręczników techniki-informatyki. Rzeszów, Poland: Wyd. Uniwersytetu Rzeszowskiego.

[11] Walat, W. (2007). Educational applications of hypermedia. Poland: Ed. University.

[12] Walat, W. (2012). Technologie informacyjne (TIK) podstawą rewolucji kognitywistycznej w szkole. Technika a Vzdelávanie, (2).

IRTIIE Vol. 7, No. 3, 2019 ISSN 1314-8788 (print), ISSN 1314-8796 (online), doi: 10.15547/artte.2019.03.007 


\section{IDTTE C Journal of the Faculty of Technics and Technologies, Trakia University https://sites.google.com/a/trakia-uni.bg/artte/}

[13] Yahupov, V. V. (2004). The Modelling of Learning Process as a Pedagogical Problem. Ongoing Professional Education: Theory and Practice: Research and Methodic Journal, (1), 28-37.

[14] Yahupov, V. V. (2013). Modelling of Professional Competence of the Alumni of Professional Educational Establishments. New Learning Technologies, 144-152.

[15] Ziaziun, I. A. (2004). The Philosophy of Pedagogical Outlook. Professional Education: Pedagogics and Psychology, (4), 209-221. 